\title{
Correction: Chondrocyte density, proteoglycan content and gene expressions from native cartilage are species specific and not dependent on cartilage thickness: a comparative analysis between rat, rabbit and goat
}

Norazian Kamisan, Sangeetha Vasudevaraj Naveen, Raja Elina Ahmad and Tunku Kamarul

\section{Correction}

After the article was published [1], we became aware that the name of our corresponding author was not correct. It should have been Tunku Kamarul [2,3] AND NOT Kamarul Tunku.

We hope that you are able to make the necessary amendments to this error and apologize for any inconvenienced caused as the result of this misprint.

\section{Received: 18 June 2013 Accepted: 8 July 2013}

Published: 10 July 2013

\section{References}

1. Kamisan N, Vasudevaraj Naveen S, Elina Ahmad R, Kamarul T: Chondrocyte density, proteoglycan content and gene expressions from native cartilage are species specific and not dependent on cartilage thickness: a comparative analysis between rat, rabbit and goat. BMC Veterinary Research 2013, 9:62.

2. Mahmod Suhaeb A, Naveen S, Mansor A, Kamarul T: Hyaluronic acid with or without bone marrow derived-mesenchymal stem cells improves osteoarthritic knee changes in rat model: a preliminary report. Indian J Exp Biol 2012, 50(6):383-390.

3. Tan SL, Sara Ahmad T, Selvaratnam L, Kamarul T: Isolation, characterization and the multi-lineage differentiation potential of rabbit bone marrowderived mesenchymal stem cells. J Anat 2013, 222(4):437-450.

*Correspondence: tkzrea@um.edu.my

Tissue Engineering Group, Department of Orthopaedic Surgery, NOCERAL,

Faculty of Medicine, University of Malaya, Kuala Lumpur 50603, Malaysia

Submit your next manuscript to BioMed Central and take full advantage of:

- Convenient online submission

- Thorough peer review

- No space constraints or color figure charges

- Immediate publication on acceptance

- Inclusion in PubMed, CAS, Scopus and Google Scholar

- Research which is freely available for redistribution 